\title{
Caspase-mediated inhibition of sphingomyelin synthesis is involved in FasL-triggered cell death
}

\author{
E Lafont ${ }^{1,2,7}$, D Milhas ${ }^{1,2,7}$, S Carpentier ${ }^{1,2}$, V Garcia ${ }^{1,2}$, Z-X Jin $^{3}$, H Umehara ${ }^{3}$, T Okazaki ${ }^{4}$, K Schulze-Osthoff ${ }^{5}$, T Levade ${ }^{1,2}$, \\ $H$ Benoist ${ }^{1,2,6}$ and $B$ Ségui ${ }^{\star, 1,2,6}$
}

Ceramide can be converted into sphingomyelin by sphingomyelin synthases (SMS) 1 and 2 . In this study, we show that in human leukemia Jurkat cells, which express mainly SMS1, Fas ligand (FasL) treatment inhibited SMS activity in a dose- and timedependent manner before nuclear fragmentation. The SMS inhibition elicited by FasL (1) was abrogated by benzyloxycarbonyl valyl-alanyl-aspartyl-(0-methyl)-fluoromethylketone (zVAD-fmk), a broad-spectrum caspase inhibitor; (2) did not occur in caspase-8-deficient cells and (3) was not affected in caspase-9-deficient cells. Western blot experiments showed SMS1 cleavage in a caspase-dependent manner upon FasL treatment. In a cell-free system, caspase-2, $-7,-8$ and -9 , but not caspase-3 and -10 , cleaved SMS1. In HeLa cells, SMS1 was Golgi localized and relocated throughout the cytoplasm in cells exhibiting an early apoptotic phenotype on FasL treatment. zVAD-fmk prevented FasL-induced SMS1 relocation. Thus, FasL-mediated SMS1 inhibition and relocation depend on caspase activation and likely represent proximal events in Fas signaling. FasL-induced ceramide production and cell death were enhanced in cells stably expressing an siRNA against SMS1. Conversely, in cells stably overexpressing SMS1, FasL neither increased ceramide generation nor efficiently induced cell death. Altogether, our data show that SMS1 is a novel caspase target that is functionally involved in the regulation of FasL-induced apoptosis.

Cell Death and Differentiation (2010) 17, 642-654; doi:10.1038/cdd.2009.130; published online 25 September 2009

Fas (CD95) engagement by Fas ligand (FasL; CD95L, $\mathrm{CD178)}$ has a crucial function in the regulation of $\mathrm{T}$-cell homeostasis, essentially through cell death induction in activated T cells. FasL-induced T-cell death is viewed as an essential negative regulatory mechanism of T-cell activation, limiting T-cell reactivity in immune responses and autoimmune diseases. In humans, gene mutations affecting either FasL, Fas or Fas signaling proteins such as initiator caspases are responsible for autoimmune lymphoproliferative syndrome. ${ }^{1}$

Scaffidi et $a l^{2}{ }^{2}$ reported the existence of two different cell types as defined by distinct Fas signaling routes. Type 1 cells were originally defined by their capacity to form large amounts of the death-inducing signaling complex (DISC), consisting in the recruitment of the adapter protein FADD and initiator caspase- 8 and -10 to the Fas receptor on activation. ${ }^{3-5}$ This enables a strong and direct activation of the caspase cascade independently of mitochondrial events. In contrast, type 2 cells, such as Jurkat T leukemia cells, form a DISC less efficiently than do type 1 cells, and require an amplifying signal from mitochondria for apoptosis induction. During this process, the DISC-activated initiator caspase-8 and -10 cleave the Bcl-2 family member Bid, which induces cytochrome $c$ release and subsequent triggering of the mitochondrial caspase cascade. ${ }^{6-9}$ It has been recently reported that internalization of the Fas receptor is required for efficient DISC formation and apoptosis induction in type 1 but not type 2 cells. ${ }^{10}$

A growing body of evidence supports the involvement of ceramide, a sphingolipid bioactive molecule, or its metabolites, in stress-induced apoptosis (for a recent review, see Ségui et al. ${ }^{11}$ ). This ceramide-induced cell death is inhibited by the overexpression of $\mathrm{Bcl}-2$ or $\mathrm{Bcl}-\mathrm{xL}$, suggesting the involvement of mitochondrial events. ${ }^{11}$ Ceramide can be generated by the breakdown of the membrane phospholipid sphingomyelin (SM) as a consequence of sphingomyelinase (SMase) activation and/or increased de novo synthesis. Ceramide is synthesized within the endoplasmic reticulum and is converted in the Golgi to SM and glucosylceramide (GlcCer) by sphingomyelin synthase (SMS) and GlcCer

${ }^{1}$ Cancer Department, U858 INSERM, Equipe 14, BP84225, 31432 Toulouse cedex 4, France; ${ }^{2}$ Cancer Department, Institut de Médecine Moléculaire de Rangueil, IFR31, Bâtiment L3, Avenue Jean Poulhes, BP84225, 31432 Toulouse cedex 4, France; ${ }^{3}$ Division of Hematology and Immunology, Department of Internal Medicine, Kanazawa Medical University, Ishikawa 920-0293, Japan; ${ }^{4}$ Department of Clinical Laboratory, Medicine/Hematology, Faculty of Medicine, Tottori University, Yonago, Tottori 683-8504, Japan; ${ }^{5}$ Interfaculty Institute for Biochemistry, University of Tübingen, Hoppe-Seyler-Str. 4, Tübingen 72076, Germany; ${ }^{6}$ Faculté des Sciences Pharmaceutiques, Service d'Immunologie, Université Paul Sabatier (Toulouse III), 35 chemin des maraîchers, 31062 Toulouse cedex 4, France

${ }^{*}$ Corresponding author: B Ségui, U858 INSERM, Institut de Médecine Moléculaire de Rangueil, BP 8422531432 , Equipe 14, Toulouse Cédex 4, France.

Tel: + 335613 23534; Fax: + 335613 22084; E-mail: bruno.segui@ inserm.fr

${ }^{7}$ These authors contributed equally to this work.

Keywords: CD95; sphingomyelin synthase 1; ceramide; apoptosis; cancer cells

Abbreviations: ALPS, autoimmune lymphoproliferative syndrome; Bcl-2/xL, B-cell lymphoma-2/xL; DAG, diacylglycerol; DISC, death-inducing signaling complex; FasL, Fas ligand; GIcCer, glucosylceramide; GCS, glucosylceramide synthase; SM, sphingomyelin; SMS, sphingomyelin synthase; TLC, thin layer chromatography; zVAD-fmk, benzyloxycarbonyl valyl-alanyl-aspartyl-( $O$-methyl)-fluoromethylketone

Received 19.1.09; revised 22.7.09; accepted 10.8.09; Edited by JP Medema; published online 25.9.09 
synthase (GCS), respectively. Both enzymes are capable of negatively regulating intracellular ceramide concentrations and are inhibited upon various stress conditions, which trigger ceramide elevation and cell death. ${ }^{11}$ Tepper et al. ${ }^{12}$ previously reported that GCS does not regulate ceramide generated on Fas cross-linking. A more recent study indicates that Fas engagement is accompanied by the inhibition of an SMS activity and ceramide increase within the nucleus. ${ }^{13}$ Different stimuli, including TNF $\alpha$, photodynamic therapy and UVB, have been shown to inhibit de novo SM synthesis. ${ }^{14-17}$ Although homotrimerization of CERT (ceramide transfer protein) has been implicated in UVB-mediated inhibition of SM synthesis, the underlying mechanisms involved are largely unknown. ${ }^{17}$

Two different mammalian genes encoding SMS have been cloned so far. ${ }^{18,19}$ The corresponding proteins, SMS1 and SMS2, are both localized at the Golgi, SMS2 being localized at the plasma membrane as well. ${ }^{18}$ Both SMS1 and 2 transfer the phosphocholine moiety from phosphatidylcholine $(P C)$ to ceramide to generate SM and diacylglycerol (DAG). As SMS1 and 2 initiate in opposite directions the formation of two important biologically active lipids, that is, ceramide and DAG, having opposite effects on cell death, SMS has been proposed as a putative regulator of cell survival and cell growth. As a matter of fact, ceramide decrease and DAG increase have been associated with a higher SMS activity in SV40-transformed fibroblasts than in normal counterparts. ${ }^{20}$ In HeLa cells, SMS1 or SMS2 silencing resulted in intracellular ceramide accumulation and cell-cycle arrest. ${ }^{21}$ In addition, different reports indicate antiapoptotic functions for SMS. In patients, a decreased intracellular ceramide level was associated with a higher SMS activity in chemoresistant leukemia. ${ }^{22}$ Recently, SMS1 has been identified by screening a mouse T-cell cDNA library in Saccharomyces cerevisiae as a suppressor of the growth-inhibitory effect of Bax and other cytotoxic stimuli, including hydrogen peroxide, heat shock, osmotic stress and exogenous ceramide. ${ }^{23}$ The expression of SMS1 in yeast could limit ceramide accumulation and cell death signaling. ${ }^{23}$ Moreover, SMS1 overexpression protected Jurkat cells from phototherapy-induced cell death, ${ }^{15}$ whereas SMS1 or SMS2 knockdown sensitized cells. ${ }^{16}$ SMS1 overexpression was also partially protective against apoptosis of oligodendroglioma cells triggered by staurosporine. ${ }^{24}$ In addition, the expression of CERT, which is required for SM synthesis, ${ }^{25}$ was increased in drug-resistant cell lines and in residual ovarian tumors after paclitaxel treatment. ${ }^{26}$ Moreover, CERT knockdown significantly sensitized cancer cells to multiple anticancer drugs. ${ }^{26}$

Nevertheless, three reports suggested a proapoptotic function of SMS. Murine lymphoma cells, completely deficient for SMS activity and lacking SM, were resistant toward alkyllysophosphatidylcholine. ${ }^{27}$ Fas-mediated apoptosis was partly impaired in a murine leukemia cell line deficient in SMS, and overexpression of SMS1 restored full caspase activation and cell death. ${ }^{28}$ Thus, a complete and sustained inhibition of SMS might alter membrane composition and properties through SM depletion and confer partial cell death resistance. ${ }^{11}$ More recently, an overexpression of SMS1 or 2 in Chinese hamster ovarian cells enhanced TNF-induced apoptosis, whereas SMS1 or 2 knockdown in THP-1-derived macrophages was partially protective against cell death mediated by LPS. ${ }^{29}$ Protection from LPS-induced cell death has been further shown to be mediated by an impaired membrane recruitment of TLR4 signaling complexes in macrophages of SMS2 knockout mice. ${ }^{30}$

This study aimed at investigating the function of SM biosynthesis in the regulation of FasL-induced cell death. We show that Fas-mediated apoptosis is associated with a profound inhibition of SM synthesis, which likely involved the caspase-mediated cleavage and relocation of SMS1. Furthermore, our finding that downregulation of SMS1 sensitized cells to apoptosis, whereas SMS1 overexpression had opposite effects, strongly underscores the importance of SM metabolism for the regulation of FasL-triggered cell death.

\section{Results}

FasL triggers caspase-dependent inhibition of de novo SM synthesis. In Jurkat cells, SM represents the most abundant sphingolipid (approximately $70 \%$ of total sphingolipids), whereas ceramide content averages $8 \%$ of $\left[{ }^{3} \mathrm{H}\right]$ sphingosine-labeled lipids (Figure 1a). FasL treatment induced profound changes in the sphingolipid pattern (Figure 1a). Notably, ceramide content strongly increased in a time-dependent manner up to $20 \%$, concomitantly to SM decrease and cell death induction (Figure $1 b$ and $c$ ). In sharp contrast, no or little variation was observed for the cellular content of GlcCer and lactosylceramide (Figure 1b). SM decrease and ceramide increase were likely a consequence of SMase activation, as FasL has been reported to activate both neutral and acidic SMases. ${ }^{31}$ We hypothesized, however, that an inhibition of SM synthesis might also account for the observed changes in sphingolipid levels. Indeed, incubation with FasL elicited a sustained and substantial inhibition of SM synthesis, which was already detectable within $1 \mathrm{~h}$ and was almost complete after $4 \mathrm{~h}$ of treatment (Figure 1d). The inhibition of SM synthesis occurred concomitantly to apoptosis induction (Figure 1c) and ceramide generation (Figure $1 e$ and $f$ ). It is noteworthy that de novo PC synthesis was also inhibited in FasL-treated Jurkat cells (Supplementary Figure 1).

We next measured in situ SMS and GCS activities by monitoring in intact cells the conversion of a fluorescent analog of ceramide into SM and GlcCer, respectively. Although GCS activity remained unaffected during the first $4 \mathrm{~h}$, FasL triggered the inhibition of SMS (up to $90 \%$ ) in a time(Figure 2a) and dose- (Supplementary Figure 2B) dependent manner. Inhibition of in situ SMS activity might be a direct (cleavage and inactivation of SMS) or indirect (for instance, decrease of endogenous substrate production and/or accessibility) consequence of caspase activation. We next measured SMS-specific activity (i.e., under conditions allowing SMS measurement using an excess of exogenous substrates). SMS-specific activity was significantly decreased in protein extracts of FasL-treated Jurkat cells (Supplementary Figure $2 \mathrm{C}$ ). The addition of benzyloxycarbonyl valyl-alanylaspartyl-(O-methyl)-fluoromethylketone (zVAD-fmk) to the culture medium abrogated this phenomenon (Supplementary Figure 2C), indicating that SMS enzymes may be directly 
a

Untreated

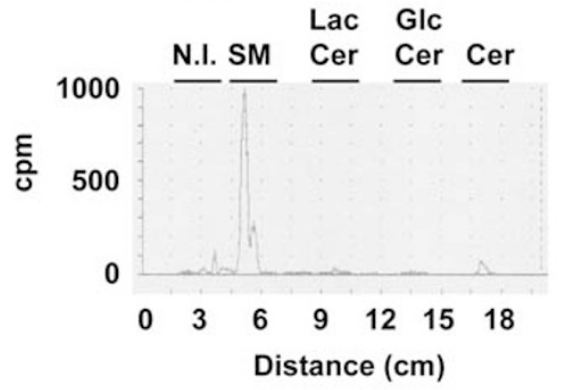

FasL

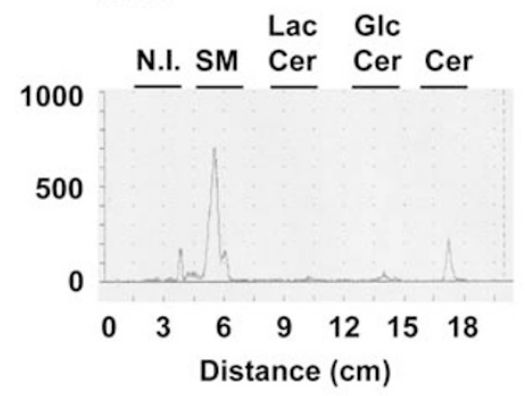

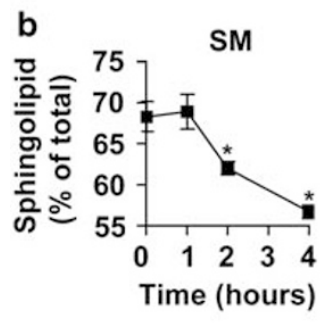
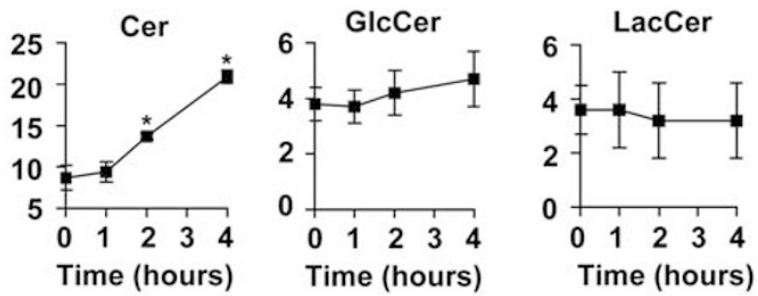

C

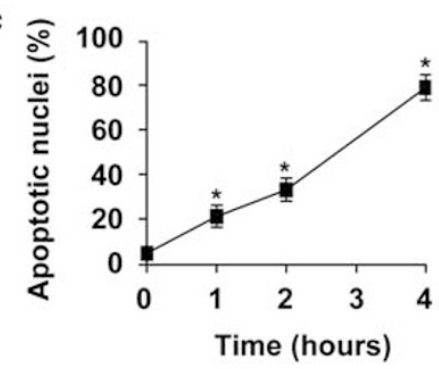

e

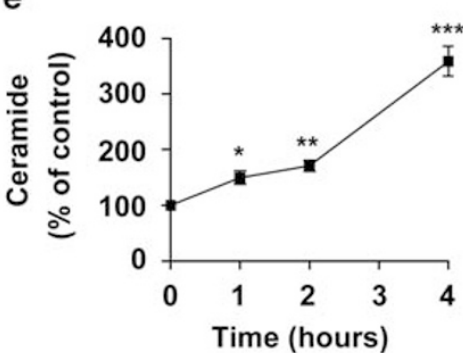

d

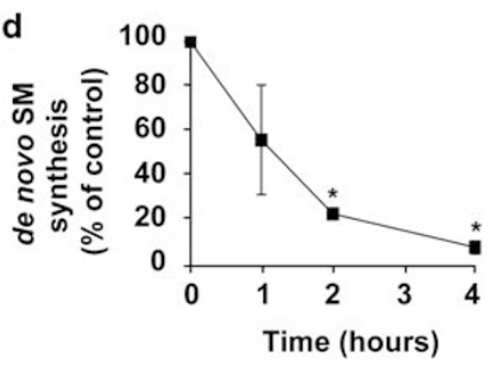

f

hours + FasL 011224

Phosphatidic acid

Ceramide-1P

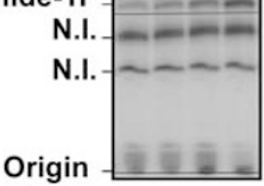

Figure 1 Treatment of Jurkat cells with FasL alters the sphingolipid content and inhibits SM synthesis. (a and $\mathbf{b}$ ) Jurkat cells (clone A3) were incubated for $48 \mathrm{~h}$ in the presence of $\left[{ }^{3} \mathrm{H}\right]$ sphingosine $(0.33 \mu \mathrm{Ci} / \mathrm{ml})$. Cells $\left(3 \times 10^{6}\right)$ were further incubated for $4 \mathrm{~h}(\mathbf{a})$ or for indicated times $(\mathbf{b})$ in the presence (FasL) or absence (untreated) of $500 \mathrm{ng} /$ $\mathrm{ml}$ FasL. Lipids were extracted and separated by TLC. (a) The sphingolipid pattern was analyzed by a radiochromatoscanner and representative images of four independent experiments are shown: nonidentified (NI) sphingolipids (possibly GM3), sphingomyelin (SM), lactosylceramide (LacCer), glucosylceramide (GlcCer) and ceramide (Cer). (b) The radioactivity in each lipid was quantified and expressed as the percentage of total sphingolipids present in the organic phase including the nonidentified (NI) sphingolipids. It is noteworthy that no variation of these nonidentified sphingolipids was observed upon FasL incubation (means \pm S.E.M., $n=4$; data not shown). (c and d) Cells $\left(3 \times 10^{6}\right)$ were incubated in the presence of $\left.{ }^{3} \mathrm{H}\right]$ choline $(1 \mu \mathrm{Ci} / \mathrm{ml})$ for $4 \mathrm{~h}$ to allow phosphatidylcholine labeling and were further incubated for indicated times in the presence or absence of $500 \mathrm{ng} / \mathrm{ml}$ FasL. The proportion of cells exhibiting apoptotic nuclei (i.e., condensed and/or fragmented nuclei) was evaluated by microscopic analysis (c). $\left[{ }^{3} \mathrm{H}\right]$ choline-labeled SM was quantified after alkaline methanolysis and results are expressed as the percentage of $\left[{ }^{3} \mathrm{H}\right]$ choline-labeled SM measured in cells incubated in the absence of FasL at each corresponding time (d). (e and f) Cells $\left(3 \times 10^{6}\right)$ were incubated for indicated times in the presence or absence of $500 \mathrm{ng} / \mathrm{ml} \mathrm{FasL}$, and ceramide content was evaluated by DAG kinase assay. (f) Representative TLC plate: NI, nonidentified; phosphatidic acid, which results from the phosphorylation of DAG by DAG kinase, remained stable over time, indicating no change in total intracellular DAG in Fas signaling. (c-e) Data are means \pm S.E.M. of three independent experiments carried out in duplicate. ${ }^{*} P<0.05,{ }^{* *} P<0.01,{ }^{* \star *} P<0.001$

cleaved and inactivated by caspases. Interestingly, specific SMS activity was time dependently decreased on FasL treatment. This decrease was already significant at $15 \mathrm{~min}$, before nuclear condensation and/or fragmentation and ceramide increase as evaluated both by DAG kinase assay
(Figure 2b) and mass spectrometry (Figure 2c). Mass spectrometry analysis indicated that $\mathrm{C} 16: 0$ ceramide was the major ceramide species in Jurkat cells and a $4 \mathrm{~h}$ FasL treatment triggered a significant increase in all detectable ceramide species (Figure 2c). 

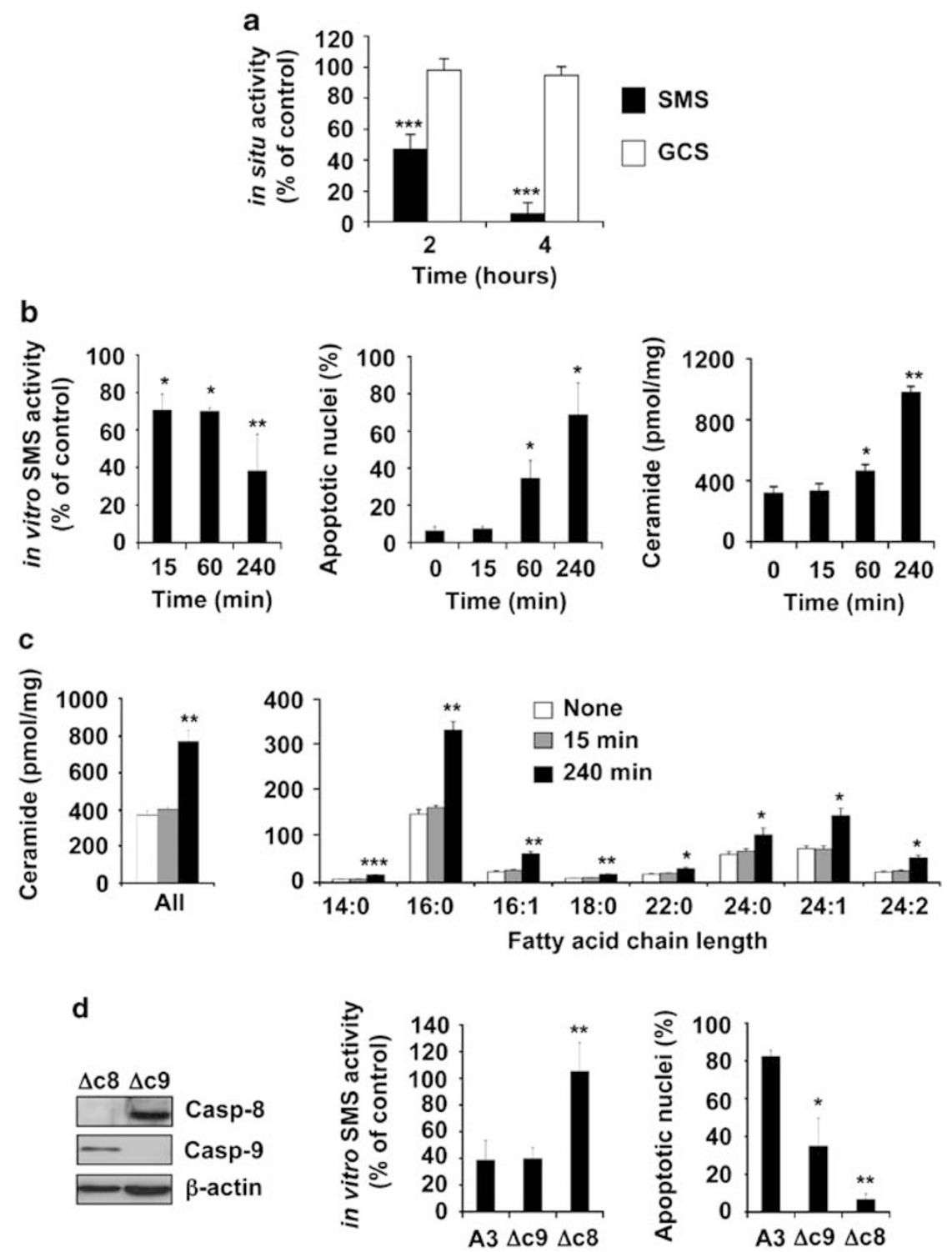

Figure 2 FasL triggers caspase-dependent inhibition of SMS activity. (a-c) Jurkat cells (clone A3) were incubated in the presence or absence of $500 \mathrm{ng} / \mathrm{ml}$ FasL for indicated times. (a) In situ SMS and GCS activities were measured by adding $2.5 \mu \mathrm{M} \mathrm{C}_{6}$-NBD-ceramide to the culture medium $2 \mathrm{~h}$ before stopping the reaction. (b) Specific SMS activity was measured on $200 \mu \mathrm{g}$ protein extracts (basal activity: $28 \pm 8 \mathrm{pmol} / \mathrm{h} / \mathrm{mg}$ ) and results are expressed as the percentage of untreated cells. The proportion of cells exhibiting apoptotic nuclei was evaluated by microscopic analysis. Ceramide was quantified by DAG kinase assay. (c) Ceramide was quantified by mass spectrometry. (d) Wild-type (clone A3), caspase-8-deficient ( $\Delta c 8$, 19-2e variant) and caspase-9-deficient ( $\Delta c 9$, JMR variant) Jurkat cells were incubated for $4 \mathrm{~h}$ in the presence or absence of $500 \mathrm{ng} / \mathrm{ml}$ FasL. Specific SMS activity and apoptosis were evaluated as above. (d) Left, western blot on protein extracts derived from $\Delta c 8$ and $\Delta c 9$ with anti-caspase-8, anticaspase-9 and anti- $\beta$-actin. (a-d) Data are means \pm S.E.M. of three independent experiments. ${ }^{\star} P<0.05,{ }^{* *} P<0.01,{ }^{* \star *} P<0.001$

To further explore the mechanism responsible for FasL-induced SMS inhibition, we evaluated the impact of the deficiency of either caspase-8 or -9 in Jurkat cells. FasL-induced apoptosis and inhibition of SMS activity were completely abolished in caspase-8-deficient (variant 19-2e) Jurkat cells (Figure 2d), in which caspase cascade activation was abrogated. ${ }^{8}$ Although caspase- 9 deficiency significantly protected against FasL-induced cell death (Figure 2d), ${ }^{32}$ SMS inhibition still occurred in caspase-9-deficient (clone JMR) Jurkat cells (Figure 2d).

Altogether, our data indicate that FasL-mediated inhibition of SMS activity is not a mere consequence of cell death and occurs through a caspase-dependent pathway, in between the activation of caspase- 8 and -9 .

SMS1 is Golgi localized and is a putative target for various caspases. The expression of SMS1 and SMS2 was next evaluated by quantitative real-time polymerase chain reaction (PCR) in Jurkat cells. Cycle threshold $\left(C_{\mathrm{t}}\right)$ values for SMS1 and SMS2 were 24.6 \pm 0.3 and $29.7 \pm 0.7$ (mean \pm S.E.M., $n=3$ ), respectively, suggesting that SMS1 is the predominant isoform in Jurkat cells, in agreement with a recent study. ${ }^{33}$ Similar findings were reported in S49, a murine lymphoma cell line. ${ }^{27}$ Considering the ability of FasL 
to trigger a caspase-dependent inhibition of SMS activity in Jurkat cells, we hypothesized that SMS1 is a putative target of caspases.

To evaluate whether SMS1 is a direct caspase substrate, we used HeLa cells stably expressing human SMS1, which was tagged with the V5 epitope at the C terminus. ${ }^{18}$ In HeLa cells stably overexpressing V5-tagged SMS1, the overexpressed enzyme partially colocalized with the Golgi protein GM130, as revealed by the use of an anti-V5 antibody (Figure 3a). Very similar results were obtained using a polyclonal anti-SMS1 antibody directed against full-length human recombinant SMS1 (data not shown). It is noteworthy that this antibody also recognized the full-length human recombinant SMS1, as well as the overexpressed V5-tagged SMS1, by western blot (data not shown). Importantly, we also observed a partial colocalization of endogenous SMS1 with GM130, further indicating that SMS1 is indeed Golgi localized (Figure 3b). On FasL treatment, SMS1 was relocated throughout the cytoplasm in cells exhibiting nuclear conden- sation. In early apoptotic cells, SMS1 and GM130 were still partially colocalized, strongly suggesting that the apparent SMS1 relocation was a consequence of Golgi fragmentation (Figure 3c). Moreover, SMS1 was hardly detectable in cells having fragmented nuclei (Figure 3c; Supplementary Figure 3). Similar findings were observed for GM130 (Figure 3c), which has been reported to be a putative caspase substrate in Fas signaling, ${ }^{34}$ indicating that SMS1 is not the unique Golgi protein, the expression pattern of which is altered on FasL treatment. FasL did not change the SMS1 distribution pattern when cells were incubated in the presence of zVAD-fmk (Supplementary Figure 3). Thus, our data indicate that FasL triggered a caspase-dependent redistribution and disappearance of SMS1, suggesting that SMS1 is putatively degraded by caspases in Fas signaling.

To further evaluate this hypothesis, western blot analyses were performed to test whether SMS1 is cleaved by caspases. Western blot using an anti-SMS1 antibody was initially carried out on protein extracts derived from untreated a contrast

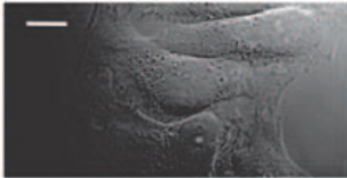

v5

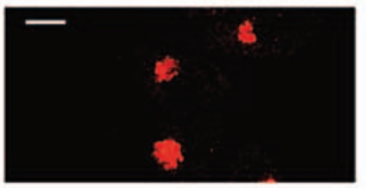

b

Phase contrast

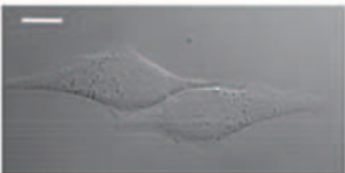

SMS1

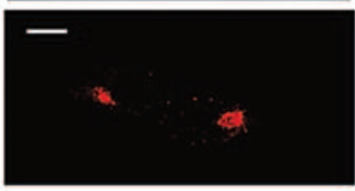

GM130
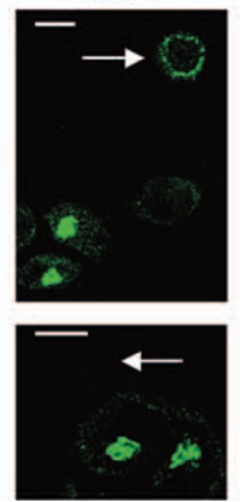
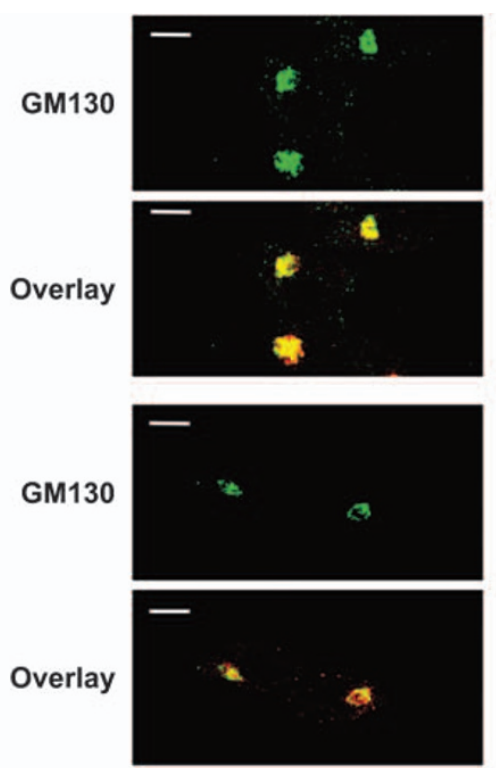

V5
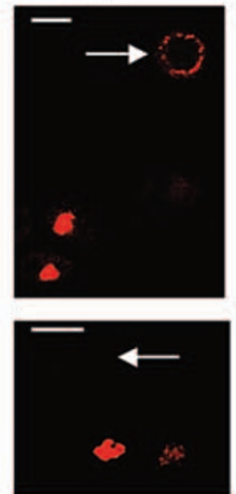

Overlay
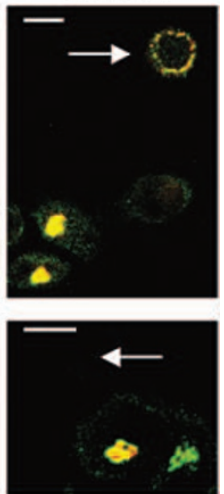

Figure 3 SMS1 is Golgi localized and relocated on FasL treatment. SMS1-V5-overexpressing (a and $\mathbf{c}$ ) and mock-transfected (b) HeLa cells were labeled with antiGM130, anti-V5 or anti-SMS1 antibodies, as indicated. (c) Cells were incubated in the presence or absence of $125 \mathrm{ng} / \mathrm{ml}$ FasL for $8 \mathrm{~h}$ and labeled with indicated antibodies. (a-c) Analyses were performed by confocal microscopy and data are representative of at least three independent experiments. Bars $=10 \mu \mathrm{m}$ 


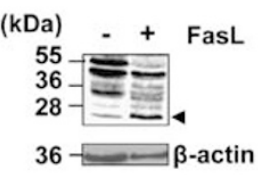

b

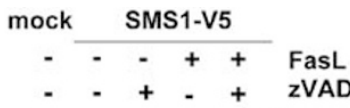

55
36

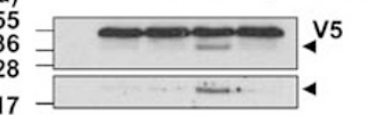

$C_{\text {(kDa) None c3 c2 c9 c8 c10 }}$
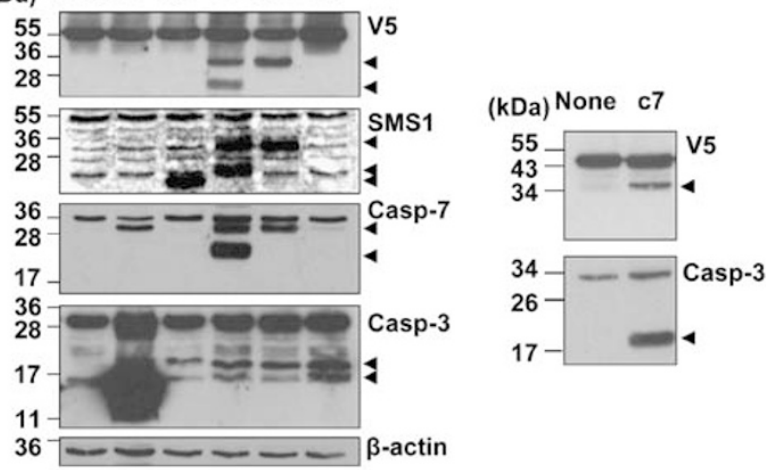

d (kDa) None c2 c8 c9

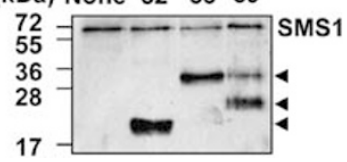

Figure 4 SMS1 is cleaved upon FasL treatment in a caspase-dependent manner. (a) Jurkat cells (clone A3) were incubated for $4 \mathrm{~h}$ in the presence or absence of FasL $(500 \mathrm{ng} / \mathrm{ml})$. Proteins $(50 \mu \mathrm{g})$ were analyzed by western blot using anti-SMS1 antibody. (b) Mock-transfected and SMS1-V5-overexpressing HeLa cells were incubated for $8 \mathrm{~h}$ in the presence or absence of FasL $(500 \mathrm{ng} / \mathrm{ml})$ and $40 \mu \mathrm{M}$ zVAD-fmk as indicated. Proteins $(50 \mu \mathrm{g})$ were analyzed by western blot using anti-V5 antibody. It is noteworthy that the lowest band was detected only after overexposure of the membrane. (c) Protein detergent extracts $(200 \mu \mathrm{g})$ prepared from SMS1-V5-overexpressing HeLa cells were incubated for $90 \mathrm{~min}$ in the presence or absence (none) of $3 \mathrm{U}$ active recombinant caspase-2, $-3,-7,-8,-9$ and -10 (c2, c3, c7, c8, c9 and c10). Proteins $(50 \mu \mathrm{g})$ were analyzed by western blot using anti-V5, anti-SMS1, anti-casp-7, anti-casp-3 and anti- $\beta$-actin antibodies. (d) Recombinant SMS1 $(100 \mathrm{ng}$ ) was incubated in the presence or absence (none) of $3 \mathrm{U}$ active recombinant caspase-2, -8 and -9 (c2, c8 and c9) and was analyzed by western blot using anti-SMS1 antibody. (a-d) Arrowheads indicate the cleaved forms and data are representative of two independent experiments

and FasL-treated Jurkat cells. In lysates derived from untreated cells, two main bands of approximately 50 and $55 \mathrm{kDa}$ were revealed. In protein extracts derived from FasLtreated cells, the SMS1 expression pattern was modified, with a loss of the upper band and an increase of a $20 \mathrm{kDa}$ band, pointing to a cleavage of endogenous SMS1 in Fas signaling (Figure 4a). Incubation of HeLa cells stably expressing V5tagged SMS1 with FasL triggered the appearance of two bands of about 36 and $20 \mathrm{kDa}$, as revealed by an anti-V5 antibody (Figure 4b). zVAD-fmk prevented the generation of these bands, indicating a caspase-dependent cleavage of SMS1 in Fas signaling (Figure 4b). To determine which caspase(s) might be involved in SMS1 cleavage, we carried out in vitro experiments by incubating protein extracts derived from HeLa cells overexpressing V5-tagged SMS1 in the presence of different active recombinant caspases. All tested caspases were active toward endogenous caspase-3 and/or -7 (Figure 4c). Various caspases including caspase-2, -7, -8 and -9 , but not caspase- 3 and -10 , cleaved SMS1 as revealed by the anti-V5 antibody (Figure 4c). In addition, caspase-2, -8 and -9 cleaved recombinant human SMS1, further suggesting that SMS1 could be a direct substrate of those initiator caspases (Figure 4d).

Collectively, our data indicate that at least three initiator caspases, caspase-2, -8 and -9 , and the effector caspase- 7 may cleave and inactivate SMS1 in Fas signaling.

SMS1 knockdown enhances FasL-induced ceramide increase and apoptosis in Jurkat and HeLa cells. To evaluate whether the inhibition of SMS1 may be a causal event in FasL-induced ceramide generation and apoptosis rather than a simple consequence of cell death, we initially knocked down SMS1 expression in Jurkat cells. Jurkat cell lines stably expressing siRNA against SMS1 have been recently characterized. ${ }^{33}$ Expression of SMS1 mRNA in the SMS1 knockdown (KD) Jurkat variant (SMS1 KD) was reduced by approximately $40 \%$ as evaluated by quantitative real-time $\mathrm{PCR}^{33}$ and analytical RT-PCR (Figure 5a), compared with Jurkat cells stably transfected with scrambled siRNA (control). It is noteworthy that SMS2 mRNA was not detected by RT-PCR in both control and SMS1 KD Jurkat cells (Figure 5a). SMS1 KD Jurkat cells showed approximately $40 \%$ reduction in SMS activity but retained normal GCS activity as compared with control Jurkat cells (Figure $5 \mathrm{~b}$; Jin et $a l .{ }^{33}$ ). Notably, the two variants showed a similar expression of Fas, FADD, caspase-8, -3 and -7 , PARP and RIP, as evaluated by flow cytometry and western blotting (data not shown). Whereas SMS1 knockdown did not significantly impair the basal ceramide content (Figure $5 \mathrm{c}$ ), the level of total SM was reduced by $15-20 \%$ in SMS1 KD as compared with that in control Jurkat cells (data not shown; Jin et al. ${ }^{33}$ ). Upon FasL treatment, the increase in ceramide (Figure $5 \mathrm{c}$ and d) and the decrease in SM (Figure $5 d$ ) levels became further pronounced in SMS1 KD Jurkat cells.

SMS1 KD Jurkat cells and control cells were analyzed to further evaluate the importance of SMS inhibition in FasLinduced cell death. The knockdown of SMS1 clearly sensitized Jurkat cells to FasL-induced cell death (Figure 5e and f). In HeLa cells, transient SMS1 knockdown was accompanied by substantial SMS activity reduction (Figure 6a) and significantly sensitized cells to FasL-induced apoptosis (Figure 6b).

SMS1 overexpression impairs FasL-induced ceramide increase and apoptosis in HeLa cells. We next evaluated the impact of SMS1 overexpression on FasL-induced ceramide production and cell death in HeLa cells. Compared with mock-transfected cells, HeLa cells overexpressing V5-tagged SMS1 showed a higher SMS activity and a lower GCS activity (Figure 6c). Moreover, SMS1 overexpression strongly impaired FasL-induced toxicity (Figure 6d) and ceramide increase (Figure 6e). It is noteworthy that HeLa cells overexpressing SMS1 were resistant toward all tested FasL concentrations (15-500 ng/ $\mathrm{ml}$ ) (Figure 6d). The resistance conferred by SMS1 overexpression was associated with a significant attenuation of FasL-induced apoptosis (Figure 6f). Finally, 
a

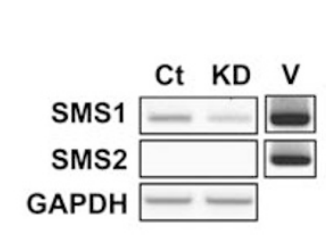

d

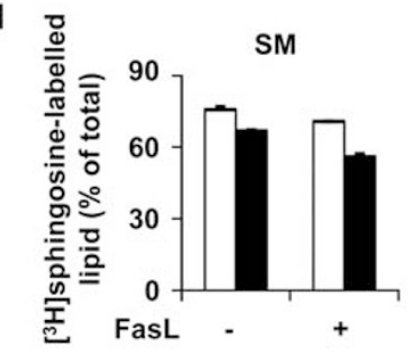

e

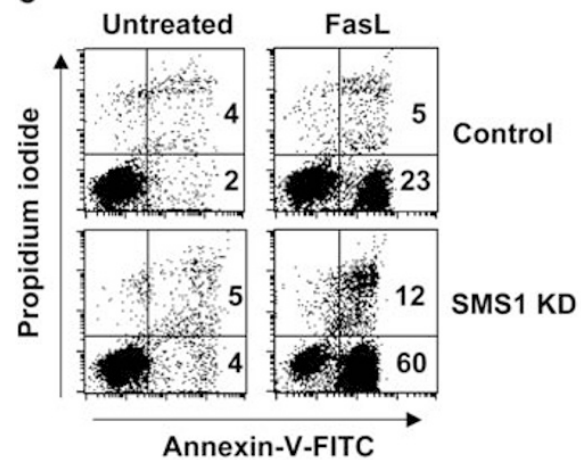

b

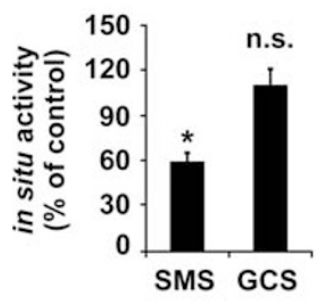

c $\square$ Control

- SMS1 KD

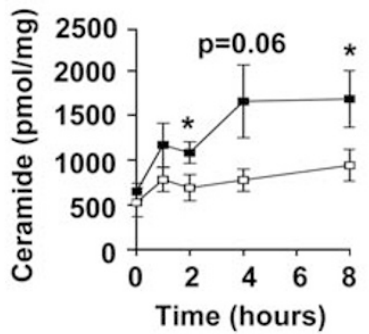

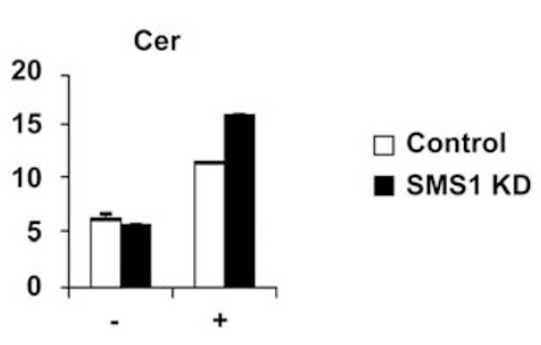

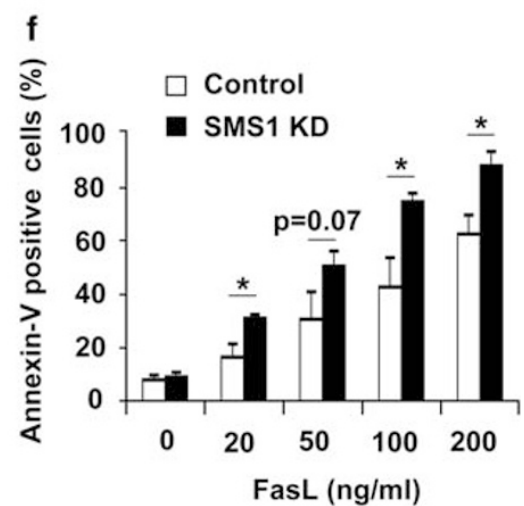

Figure 5 SMS1 silencing enhances FasL-induced ceramide production and apoptosis. (a) SMS1, SMS2 and GAPDH mRNA expression in SMS1 knockdown (KD) and control (Ct) Jurkat cells was analyzed by RT-PCR. Vectors (V) containing either SMS1 or SMS2 cDNA were used as positive controls for PCR. (b) SMS1 KD and control Jurkat cells were incubated in the presence of $2.5 \mu \mathrm{M} \mathrm{C}_{6}$-NBD-ceramide for $2 \mathrm{~h}$. SMS and GCS activities were determined by quantifying fluorescent SM and GlcCer. SMS and GCS activities in SMS1 KD Jurkat cells are expressed as the percentage of those measured in control cells. Data are means \pm S.E.M. of three independent experiments. (c) Cells were incubated for indicated times in the presence or absence of $100 \mathrm{ng} / \mathrm{ml} \mathrm{FasL}$. Ceramide content was determined by DAG kinase assay (means \pm S.E.M., $n=4$ ). (d) Cells were labeled with $0.33 \mu \mathrm{Ci} / \mathrm{ml}\left[{ }^{3} \mathrm{H}\right]$ sphingosine for $72 \mathrm{~h}$. After a $2 \mathrm{~h}$ chase, cells were incubated in the presence or absence of $100 \mathrm{ng} / \mathrm{ml} \mathrm{FasL} \mathrm{for} 4 \mathrm{~h}$. Lipids were extracted, separated by TLC, and the radioactivity associated with sphingomyelin (SM) and ceramide (Cer) was quantified. The radioactivity of each lipid is expressed as the percentage of total sphingolipids present in the organic phase. Values are means \pm S.E.M. of duplicate determinations. Similar data were obtained in two other experiments. (e and $\mathbf{f}$ ) SMS1 KD and control Jurkat cells were incubated for $8 \mathrm{~h}$ with FasL (100 ng/ml), (e) or at indicated concentrations (f) and were analyzed by flow cytometry after Annexin V-FITC and propidium iodide labeling. Percentages of Annexin-V-positive and propidium-iodide-negative (low right quadrants) and propidium-iodide-positive cells (upper quadrants) are indicated (e). Values are means \pm S.E.M. of three independent experiments (f). ${ }^{*} P<0.05$

transfection of SMS1 siRNA substantially decreased the overexpressed SMS1 and significantly sensitized cells to FasL (Figure 6g). The role of SMS2 in FasL-induced apoptosis has also been investigated in HeLa cells. Our findings indicate that, under certain experimental conditions, SMS2 may also negatively regulate FasL-induced apoptosis (Supplementary Figure 4).

Altogether, our results show that an increased SMS1 expression can confer resistance of cancer cells to FasL, whereas its decrease can sensitize cells.

SMS1 inhibits FasL-induced caspase activation. To delineate the molecular mechanisms involved in the inhibition of FasL-induced cell death mediated by SMS1, we analyzed caspase activation in SMS1 KD (Figure 7a) and SMS1 overexpressing (Figure 7b) cells on FasL treatment. Although caspase-3 and PARP cleavage was enhanced in SMS1 KD Jurkat cells (Figure 7a), it was significantly reduced in SMS1 overexpressing HeLa cells (Figure 7b). Accordingly, the efficiency of caspase-3 processing (that is, the disappearance of the proform and appearance of the active p17 form) inversely correlated with SMS1 expression. In addition, whereas SMS1 knockdown increased caspase-8 processing (Figure 7a), the caspase-8 cleavage remained poorly affected by SMS1 overexpression (Figure 7b). Of particular interest was the fact that FasL-induced caspase-9 

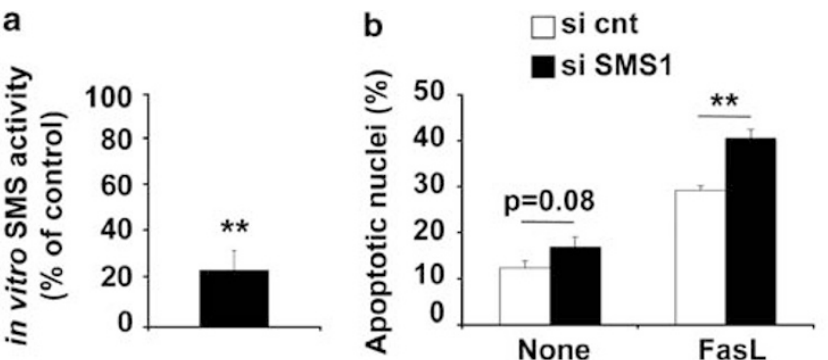

c
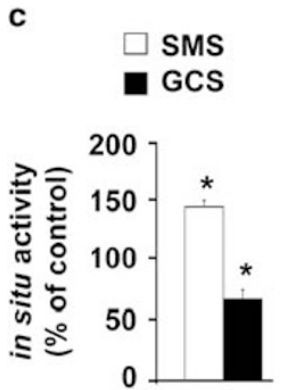

d

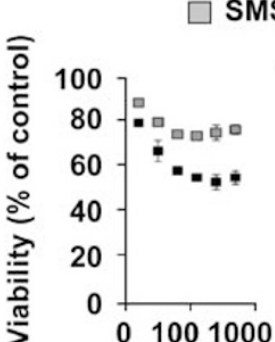

FasL $(\mathrm{ng} / \mathrm{mL})$
pcDNA3.1

SMS1-V5

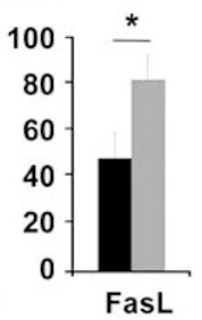

FasL e

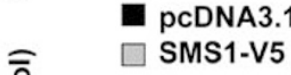

f pcDNA3.1

SMS1-V5

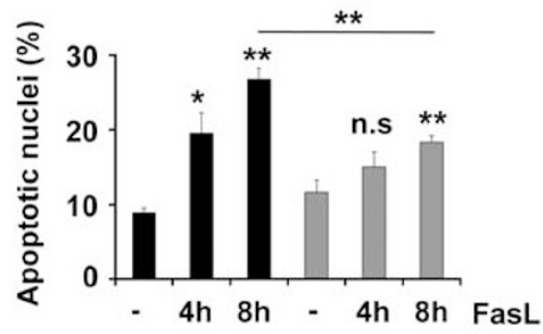

g

(kDa) si si

55
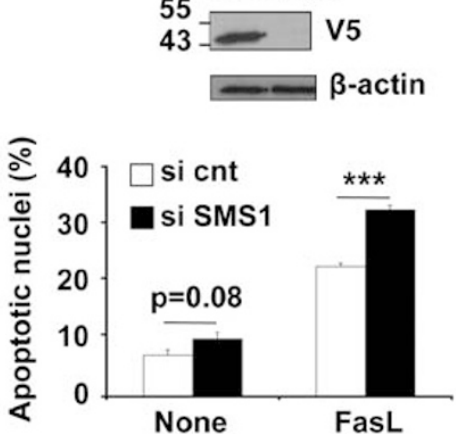

Figure 6 SMS1 levels in HeLa cells correlate with protection against FasL-induced cell death. (a and b) HeLa cells were transfected with control siRNA (si cnt) or siRNA to SMS1 (si SMS1) and were further incubated for $72 \mathrm{~h}$. (a) Specific SMS activity was measured on $200 \mu \mathrm{g}$ protein extracts (basal activity: $328 \pm 62 \mathrm{pmol} / \mathrm{h} / \mathrm{mg}$ ) and results obtained in cells transfected with siRNA to SMS1 are expressed as the percentage of cells transfected with control siRNA. (b) Cells were further incubated for $8 \mathrm{~h}$ in the presence or absence of FasL $(125 \mathrm{ng} / \mathrm{ml})$. The proportion of cells exhibiting apoptotic nuclei was evaluated by microscopic analysis. (a and $\mathbf{b})$ Data are means \pm S.E.M., $n=3$. (c) In situ SMS and GCS activities were measured in mock-transfected (pcDNA3.1) and SMS1-V5-overexpressing (SMS1-V5) HeLa cells. Data obtained in SMS1overexpressing HeLa cells are expressed as the percentage of those measured in control cells (mean \pm S.E.M., $n=3$ ). (d and $\mathbf{e}$ ) Cells were incubated for $8 \mathrm{~h}$ in the presence or absence of FasL ( $125 \mathrm{ng} / \mathrm{ml}$ or the indicated concentrations). Cell viability (d) and ceramide level (e) were assessed by MTT assay and by the DAG kinase method, respectively. Results are expressed as the percentage of untreated cells for each cell line: (d) left, data are means \pm S.E.M. of three determinations from a representative experiment; (d right and $\mathbf{e}$ ) data are means \pm S.E.M. of three independent experiments. (f) Proportion of apoptotic nuclei in mock-transfected (pcDNA3.1) and SMS1-V5overexpressing (SMS1-V5) HeLa cells incubated for indicated times in the presence or absence of $125 \mathrm{ng} / \mathrm{ml} \mathrm{FasL} \mathrm{(mean} \pm$ S.E.M., $n=3$ ). (g) SMS1-overexpressing HeLa cells were transfected with control siRNA (si cnt) or siRNA to SMS1 (si SMS1) and were further incubated for $72 \mathrm{~h}$. Inset, western blot on $50 \mu \mathrm{g}$ protein extracts using anti-V5 or anti- $\beta$-actin antibodies. Cells were further incubated for $8 \mathrm{~h}$ in the presence or absence of FasL (125 $\mathrm{ng} / \mathrm{ml})$ and the proportion of cells exhibiting apoptotic nuclei was evaluated (means \pm S.E.M., $n=3$ ). ${ }^{*} P<0.05,{ }^{\star *} P<0.01,{ }^{* \star *} P<0.001$

cleavage was greatly enhanced in SMS1 KD Jurkat cells (occurring $2 \mathrm{~h}$ before and being complete by $8 \mathrm{~h}$; Figure $7 \mathrm{a}$ ) but was significantly prevented by SMS1 overexpression in HeLa cells (with no detectable cleavage at $4 \mathrm{~h}$; Figure 7b). In addition, FasL-triggered cytochrome $c$ release was significantly decreased in SMS1-overexpressing HeLa cells as compared with that in mock-transfected cells (data not shown).
Collectively, our data indicate that SMS1 modulates caspase cascade activation on FasL treatment, acting most likely at the mitochondrial level.

\section{Discussion}

This study supports the notion that FasL-induced inhibition of SMS alters the cellular sphingolipid pattern, including SM 


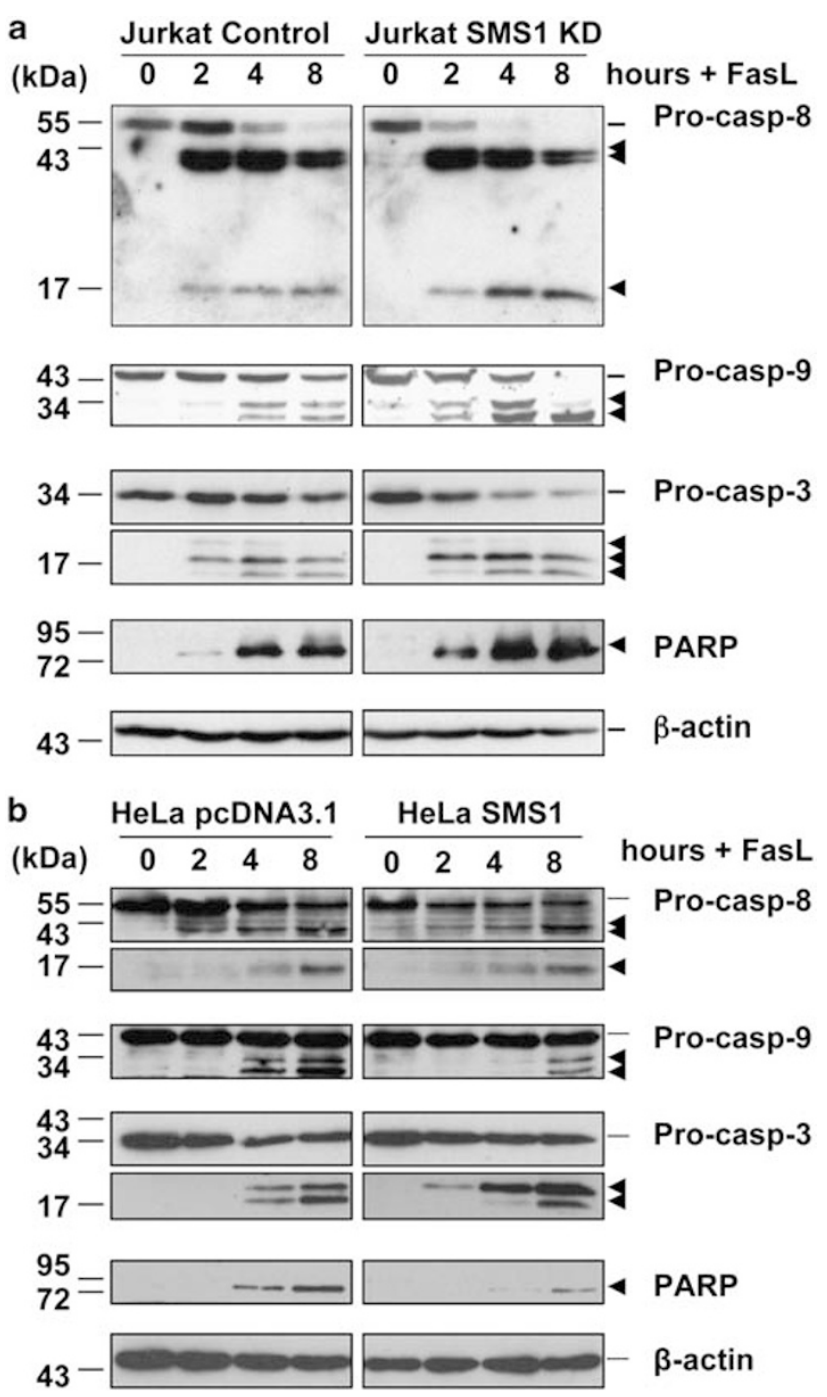

Figure 7 SMS1 inhibits FasL-triggered caspase cascade activation. Control and SMS1 KD Jurkat cells (a), and mock-transfected and SMS1-overexpressing HeLa cells (b) were incubated for the indicated times in the presence of $100 \mathrm{ng} / \mathrm{ml}$ FasL. Proteins were extracted and analyzed by western blotting using anti-caspase8 , anti-caspase- 9 , anti-caspase-3, anti-PARP and anti- $\beta$-actin antibodies. Arrowheads indicate cleaved forms. Results are representative of two independent experiments

decrease and ceramide increase, and contributes to cell death induction.

FasL-induced SMS inhibition occurred before apoptosis induction and ceramide generation through a caspasedependent process and was strongly impaired in caspase-8deficient cells but not in caspase-9-deficient cells. Thus, SMS inhibition appears as a proximal event in Fas signaling that primarily occurs in between the activation of caspase- 8 and caspase-9. In addition, our data indicate that SMS1 is a putative target of at least the effector caspase-7 and three initiator caspases including caspase-2, -8 and -9 . We also provide evidence for the first time that, similar to the overexpressed V5-tagged enzyme (see Figure $3 a$ and Huitema et al. ${ }^{18}$ ), endogenous SMS1 colocalizes with a Golgi marker (see Figure 3b), further arguing that SMS1 is indeed a Golgi protein. On FasL treatment, SMS1 relocalized throughout the cytoplasm in cells exhibiting nuclear condensation. Moreover, the loss of SMS1 expression in late apoptotic cells (that is, exhibiting nuclear fragmentation) is in favor of SMS1 proteolysis, in agreement with our western blot analyses indicating caspase-dependent SMS1 cleavage in Fas signaling (see Figure 4b).

The possibility that inhibition of SM synthesis may represent an important event in FasL-induced cell death signaling is highlighted by the enhanced sensitivity of SMS1 KD Jurkat cells to FasL. These data may seem at odds with a previous report showing FasL resistance of a mouse leukemia cell line (WR19L) deficient for SMS activity. ${ }^{28}$ In this particular mouse cell line, the reduction of SM synthesis was accompanied by a strong SM depletion in membranes, notably within lipid rafts. Thus, the initiation of Fas signaling was greatly compromised, most likely as the consequence of altered biochemical and biophysical properties of the plasma membrane. SM breakdown through acidic SMase has indeed been reported as an essential event for ceramide generation at the cell surface, facilitating Fas capping. ${ }^{11,35}$ The reduced SM content in WR19L may be limiting for ceramide generation by SMase. As a matter of fact, early events in Fas signaling, such as receptor aggregation and capping, were impaired in SMS-deficient WR19L cells. ${ }^{28}$ In this study, we used SMS1 KD Jurkat cells, which exhibited an approximately $40 \%$ inhibition of SMS activity and a $15 \%$ reduction of the total intracellular pool of $\mathrm{SM}$. Thus, one can speculate that the remaining $85 \% \mathrm{SMs}$ are sufficient for the proper relocation of Fas within the plasma membrane on FasL treatment.

In the S49 mouse lymphoma cell line, pharmacological (using U18666A) disturbance of cholesterol transport and lipid rafts was accompanied by an approximately $80 \%$ decrease in SM biosynthesis without affecting FasL-induced apoptosis. ${ }^{27}$ One should note that, under these particular experimental conditions, no direct effect on SMS enzyme activity was observed, ${ }^{27}$ in sharp contrast to our current study (see Figure $2 b$, d and Supplementary Figure 2C). In addition, we cannot rule out the possibility that the inhibition of SMS activity may enhance FasL-induced apoptosis in a cell-type-dependent manner. Our present study indicates that at least two human cancer cell lines (that is, Jurkat and HeLa cells) can be sensitized to FasL-induced apoptosis by silencing SMS1. Furthermore, the SMS2 knockdown in HeLa cells slightly enhanced FasL-induced apoptosis, although to a lesser extent as compared with SMS1 knockdown.

The high sensitivity of SMS1 KD Jurkat cells to FasLinduced apoptosis was associated with an exacerbated SM decrease and ceramide increase on Fas cross-linking. The inhibition of SM synthesis may favor ceramide accumulation by preventing the conversion of newly formed ceramide (derived from SM breakdown and/or de novo ceramide synthesis) into SM. Moreover, overexpressing SMS1 in HeLa cells altered FasL-induced ceramide generation and cell death, whereas transfection by siRNA against SMS1 sensitized HeLa cells to FasL. Thus, our data support the conclusion that SMS1 behaves as a key regulator of FasLinduced ceramide generation and cell death. In our study, total intracellular DAG levels were not significantly affected in 
Jurkat and HeLa cells on FasL treatment (data not shown). However, the possibility that FasL triggers a selective decrease in the DAG pool localized at the Golgi cannot be ruled out. Indeed, a recent report indicates that an inhibition of SMS expression by siRNA in HeLa cells may affect DAG at the Golgi, whereas total DAG remains unchanged. ${ }^{36}$

Stimulation of CD95 can activate neutral and acidic SMases, both of which catalyze SM breakdown to ceramide. ${ }^{31}$ Whereas there is no genetic evidence for (or against) a role of neutral SMases in CD95-mediated cell death, mutations in Smpd1, which encodes acidic SMase, have been associated with alterations of CD95 signaling both in human and mouse cells, suggesting a putative role of acidic SMase in CD95 signaling (for review, see Segui et al. ${ }^{11}$ ). Whereas this matter is still debated, ${ }^{11}$ this study proposes a novel mechanism that may contribute to SM decrease and ceramide increase in Fas signaling.

SMS inhibition occurred as early as $15 \mathrm{~min}$ after FasL treatment, whereas ceramide increase was detected after $1 \mathrm{~h}$ (see Figure 2b). There might be at least two explanations for this apparent discrepancy. First, during the first hour, despite SMS inhibition, ceramide did not accumulate because it can be metabolized by other sphingolipid metabolizing enzymes (such as GCS, which was not or poorly inhibited in Fas signaling; Supplementary Figure 2). This hypothesis is unlikely, as the ceramide produced on Fas cross-linking does not serve as a substrate for GCS. ${ }^{12}$ A second possibility would be that subtle changes in the ceramide concentration in the Golgi apparatus, in which SMS1 resides, may not be detected either by the DAG kinase assay or by the mass spectrometry method, both of which evaluate the total intracellular ceramide. Only more pronounced changes could be detected at later time points.

Ceramide is considered as a bioactive molecule in cell death signaling, possibly acting as a modulator of membrane structure and dynamics. ${ }^{11,37}$ The cytotoxic mechanisms initiated by ceramide are not yet fully elucidated. The ceramide derived from cell-surface SM breakdown, as a consequence of acidic SMase secretion, has been proposed to be involved in Fas capping and DISC formation. Ceramide or its metabolites can also act intracellularly in signal transduction by activating mitochondrial events including cytochrome $c$ and AIF release, as well as ROS production. As a matter of fact, low concentrations $(5-10 \mu \mathrm{M})$ of C16ceramide triggered apoptosis in wild-type and in caspase-8deficient (19-2e cells) cells but not in caspase-9-deficient (JMR cells) Jurkat cells (Lafont, Dupont, Ségui, unpublished observation). Furthermore, ceramide can promote an increase in lysosomal membrane permeability, autophagic cell death and endoplasmic reticulum stress. ${ }^{11}$ In this study, FasLtriggered caspase cascade activation was enhanced in SMS1 KD Jurkat cells and was partially inhibited in SMS1-overexpressing HeLa cells (see Figure 7). Although the processing of caspase- 8 was not drastically changed by the modulation of SMS1 expression, the cleavage of initiator caspase-9 was markedly affected. Moreover, FasL-triggered cytochrome $c$ release was significantly decreased in SMS1-overexpressing HeLa cells as compared with that in mock-transfected cells (data not shown). The latter observation indicates that the ceramide derived from the inhibition of SMS1 preferentially affects the mitochondrial pathway and caspase- 9 activation. The molecular link between mitochondria and a sphingolipidmetabolizing enzyme localized at the Golgi remains to be established. It has been recently reported that soon after Fas engagement, elements of the Golgi complex intermix with mitochondria in Jurkat cells. ${ }^{38}$ Moreover, ceramide has been shown to trigger Golgi fragmentation. ${ }^{39}$ Thus, it is tempting to speculate that the ceramide derived from the inhibition of SMS1 might contribute to Golgi fragmentation and intermix with mitochondria (or mitochondria-associated membranes). Whether ceramide increase, as a result of SMS inhibition, contributes to FasL-induced apoptosis remains to be demonstrated.

SMS2 was not as potent as SMS1 in negatively regulating FasL-induced apoptosis in HeLa cells (see Supplementary Figure 4). The overexpression of either SMS1 or SMS2 was accompanied by a similar increase in in situ SMS activity as compared with that in mock-transfected cells (see Supplementary Figure 4 and Figure 6). It is noteworthy that SMS2, but not SMS1, shows both SM and ceramide phosphoethanolamine synthase activity. ${ }^{40}$ We cannot rule out the possibility that SMS2 dual activity modulates Fas signaling. Moreover, in sharp contrast to SMS1, SMS2 has been reported to be mainly localized at the plasma membrane. ${ }^{18}$ Thus, one can speculate that early SMS1 relocation (most likely as a consequence of Golgi fragmentation) in Fas signaling contributes to the inhibition of de novo SM synthesis, thereby enhancing apoptosis signaling. Finally, because SMS1 is able to modulate vesicular transport from the Golgi to the plasma membrane, ${ }^{36}$ FasL, notably through SMS1 inhibition, may alter vesicular trafficking (an essential biological process for cell survival) ${ }^{41}$ and thereby enhance cell death.

In summary, inhibition of SM synthesis might facilitate FasL-induced ceramide increase and cell death in cancer cells. A working hypothesis is to consider that SMS1 inhibition occurs downstream of caspase- 8 activation and that the subsequently accumulated ceramide enhances FasL-induced caspase- 9 activation and cell death. In humans, SMS activity, together with GCS activity, is increased in chemoresistant leukemia cells. ${ }^{22}$ Interfering with SMS activity may represent an interesting therapeutic strategy to sensitize cells for the induction of apoptosis.

\section{Materials and Methods}

Reagents. Final concentrations or dilutions and sources of reagents were as follows: zVAD(OMe)-fmk $(40 \mu \mathrm{M})$ was purchased from Bachem (Voisins-LeBretonneux, France); polyclonal anti-SMS1 raised against a peptide derived from SMS1 was from Exalpha-Servibio (Meudon, France) and was used at 1:500 dilution; polyclonal anti-caspase-3 $(10 \mu \mathrm{g} / \mathrm{ml})$ was obtained from Dako (Trappes, France); monoclonal anticaspase-8 (clone 1C12), polyclonal anticaspase-7 and polyclonal anti-PARP were purchased from Cell Signaling Technology (SaintQuentin-en-Yvelines, France) and were used at 1:1000 dilution; monoclonal antiV5 $(0.2 \mu \mathrm{g} / \mathrm{ml})$ was from Invitrogen (Cergy Pontoise, France); monoclonal anti- $\beta$ actin (clone AC-15; $5 \mu \mathrm{g} / \mathrm{ml}$ ) was from Sigma (St. Quentin Fallavier, France). For microscopic analysis polyclonal anti-SMS1 raised against full-length recombinant SMS1 was from Exalpha-Servibio and was used at 1:50 dilution; anti-GM130 was from Santa Cruz Biotechnology-Tebu (Le Perray-en-Yvelines, France) and was used at 1:50 dilution; monoclonal anti-V5 was from Invitrogen and was used at $1: 200$ dilution. Anti-mouse, -rabbit and -goat IgGs conjugated with either Alexa 488, 633 or 647 were purchased from Molecular Probes Inc./Invitrogen and were used at $1: 500$ dilution. Human recombinant FasL was obtained from Abcys (Paris, France). Alternatively, mouse FasL produced in the supernatant of Neuro-2A cells stably 
transfected with a plasmid encoding FasL ${ }^{42}$ was used. Similar data were obtained using mouse or human FasL.

Cell lines. Parental Jurkat T leukemia cells ( $A 3$ ) and derived cell lines deficient for caspase-8 $(19-2)^{43}$ were kindly provided by Dr. J Blenis (Boston, MA, USA). 19-2d and 19-2e cells were isolated by limiting dilution experiments from 19-2 cells as previously described. ${ }^{8}$ Caspase-9-deficient Jurkat cells (clone JMR) were previously characterized. ${ }^{32}$ Jurkat cells were stably transduced by a retroviral vector encoding either a scrambled (ATTGAAAAAGACACGCGCC) (control cells) or human SMS1 siRNA (GCCCAACTGCGAAGAATAA) (SMS1 KD cells). ${ }^{33}$ HeLa cells stably overexpressing human SMS1 harboring the V5 tag at the $\mathrm{C}$ terminus ${ }^{18}$ were kindly provided by Dr. J Holthuis (Utrecht, the Netherlands). The cells were transiently transfected with either $50 \mathrm{nM}$ siRNA (siRNA On-Target SMARTpool) against SMS1 (Perbio, Brebières, France) or control (Non-Targeting SMARTpool) siRNA using Hiperfect reagent (Qiagen, Courtaboeuf, France), following the manufacturer's instructions.

Analysis of mRNA expression. Total RNA was isolated from Jurkat cells using the Qiagen RNeasy kit and reverse transcribed using oligo(dT) ${ }_{15}$ (Promega, Charbonnières, France) and Superscript II (Invitrogen), as recommended by the manufacturers. cDNAs were analyzed by quantitative real-time PCR using specific primers for SMS1, SMS2 and GAPDH (Qiagen) and the Power SYBR Green PCR Master mix (Applied Biosystems, Courtaboeuf, France). Mixtures were loaded in a TaqMan 7900 (Applied Biosystems) and amplification was performed according to the manufacturer's instructions. Alternatively, cDNAs were amplified by 30 PCR cycles using GoTaq Flexi DNA Polymerase (Promega) and specific primers for SMS1 (forward primer: $5^{\prime}$-CATTTCAACTGTTCTCCGAAGC-3'; reverse primer: $5^{\prime}$ CCATAGTGTGATACCACCAG-3'), SMS2 (forward primer: $5^{\prime}$-TTAATCTGCTGGC TGCTGAG- $3^{\prime}$; reverse primer: $5^{\prime}$-ACCAATCTTCTGAACCCGTG-3') and GAPDH (forward primer: $5^{\prime}$-AACATCATCCCTGCCTCTACTG-3'; reverse primer: $5^{\prime}$-TTGA CAAAGTGGTCGTTGAGG-3'). CDNA prepared from human skin fibroblasts and vectors carrying human CDNA for SMS1 and SMS2 were used as positive controls. Amplifications were performed in a thermal cycler (Bio-Rad, Marnes-la-Coquette, France) and amplification products were analyzed after migration into a $0.8 \%$ agarose gel, followed by ethidium bromide staining.

Flow cytometry analyses. Phosphatidylserine externalization was evaluated by labeling cells with Annexin V-FITC $(250 \mathrm{ng} / \mathrm{ml})$ and propidium iodide $(12.5 \mu \mathrm{g} / \mathrm{ml})$ (Immunotech, Marseille, France) for $10 \mathrm{~min}$ at $4^{\circ} \mathrm{C}$. Analyses were performed on a FACScan cytometer (Becton Dickinson, Le Pont-De-Claix, France). ${ }^{8}$

MTT assay. Viability was evaluated by the tetrazolium-based MTT (3-(4,5dimethylthiazol-2-yl)-2,5-diphenyltetrazolium bromide) assay. Cells were seeded in flat-bottom 96 -well plates ( $10^{6}$ cells per $\mathrm{ml}, 100 \mu \mathrm{l}$ per well) for indicated times at $37^{\circ} \mathrm{C}$. MTT $(0.5 \mathrm{mg} / \mathrm{ml}$; Sigma) was added during the last $2 \mathrm{~h}$. Formazan crystals were solubilized overnight at $37^{\circ} \mathrm{C}$ by adding $100 \mu \mathrm{l}$ of solubilization buffer $(0.01 \mathrm{~N} \mathrm{HCl}, 10 \%$ SDS) and quantified spectrophotometrically using an ELISA reader $(\lambda=560 \mathrm{~nm})$.

Protein extraction and western blotting analyses. For total protein extraction, $5 \times 10^{6}$ cells were lysed for $30 \mathrm{~min}$ on ice in a buffer containing $50 \mathrm{mM}$ HEPES (pH 7.5), $150 \mathrm{mM} \mathrm{NaCl}, 10 \%$ glycerol, $1 \%$ Triton $\mathrm{X}-100$, $0.5 \%$ deoxycholate, $1 \mathrm{mM} \mathrm{NaVO}_{4}, 10 \mu \mathrm{M} \beta$-glycerophosphate, $50 \mathrm{mM} \mathrm{NaF}, 1 \mathrm{mM}$ phenylmethylsulfonyl fluoride, $10 \mu \mathrm{g} / \mathrm{ml}$ leupeptin, $2 \mu \mathrm{g} / \mathrm{ml}$ pepstatin A and $10 \mu \mathrm{g} / \mathrm{ml}$ aprotinin. Samples were centrifuged at $3500 \times g$ at $4^{\circ} \mathrm{C}$ for $10 \mathrm{~min}$. Supernatants were collected and protein content was determined by the Bradford method (Bio-Rad). For western blot analyses, equal amounts of proteins were separated on $12.5 \%$ SDS-PAGE.

Determination of in situ SMS and GCS activities. Jurkat cells $\left(1 \times 10^{6}\right)$ were incubated in $1 \mathrm{ml}$ RPMI 1640 medium containing 10\% fetal calf serum (FCS) and $2.5 \mu \mathrm{M} \mathrm{C}_{6}$-NBD-ceramide (Sigma) solubilized in ethanol. After incubation at $37^{\circ} \mathrm{C}$ for $2 \mathrm{~h}$, the reaction was stopped and lipids were extracted from the cells and the medium by adding $5 \mathrm{ml}$ of chloroform/methanol $(2: 1, \mathrm{v} / \mathrm{v})$. After centrifugation $(1000 \times g, 10 \mathrm{~min})$, the lower phases were dried under nitrogen and resolved by analytical thin layer chromatography (TLC) developed in chloroform $/$ methanol/30\% ammonia $\left(70: 30: 5\right.$, by vol). $\mathrm{C}_{6}$-NBD-ceramide, $\mathrm{C}_{6}$-NBD-GlcCer and $\mathrm{C}_{6}$-NBD-SM were eluted from the silica and quantified spectrofluorometrically $\left(\lambda_{\mathrm{ex}}=470 \mathrm{~nm}\right.$ and $\lambda_{\mathrm{em}}=530 \mathrm{~nm}$ ).
Determination of in vitro SMS activity. Jurkat cell pellets were resuspended in water and briefly sonicated. Cell lysates (200 $\mu \mathrm{g}$ proteins) were incubated with $250 \mu \mathrm{l}$ reaction buffer ( $50 \mathrm{mM} \mathrm{HEPES}, 5 \mathrm{mM} \mathrm{MgCl}, 5 \mathrm{mM} \mathrm{MnCl}$, $1 \mathrm{mM}$ EDTA). Liposomes $(250 \mu \mathrm{l})$ containing $400 \mu \mathrm{M} \mathrm{PC}$ (Sigma) and $20 \mu \mathrm{M} \mathrm{C}_{6^{-}}$ NBD-ceramide in BSA were added. After $1 \mathrm{~h}$ incubation at $37^{\circ} \mathrm{C}$, the reaction was stopped by adding $2.5 \mathrm{ml}$ chloroform/methanol $(2: 1, \mathrm{v} / \mathrm{v})$. Fluorescent lipids were next analyzed by TLC as described earlier.

Cell-free assays of proteolysis. Cell pellets derived from HeLa cells overexpressing SMS1-V5 were resuspended in lysis buffer (10 mM HEPES-KOH (pH 7.4), $42 \mathrm{mM} \mathrm{KCl}, 5 \mathrm{mM} \mathrm{MgCl} 2,1 \mathrm{mM} \mathrm{DTT}, 0.5 \%$ CHAPS, $1 \mathrm{mM} \mathrm{PMSF}, 2 \mu \mathrm{g} / \mathrm{ml}$ leupeptin). After a brief sonication and centrifugation (10000 $\times \mathrm{g}, 10 \mathrm{~min}), 200 \mu \mathrm{g}$ proteins were incubated for $90 \mathrm{~min}$ at $37^{\circ} \mathrm{C}$ in the presence of three units (as defined by the manufacturer) of active recombinant caspases (Abcys). Alternatively, $100 \mathrm{ng}$ of recombinant GST-tagged SMS1 (Abnova, Montluçon, France) was incubated for $90 \mathrm{~min}$ at $37^{\circ} \mathrm{C}$ in the presence of three units of active recombinant caspases in lysis buffer. The reaction was stopped by freezing the samples down on liquid nitrogen and proteins were analyzed by western blot.

Ceramide and diacylglycerol mass measurement. Lipids were extracted as described above. Ceramide mass was determined as previously reported ${ }^{44}$ using Escherichia coli membranes as a source of DAG kinase (a kind gift from Dr. D Perry and Dr. YA Hannun; Charleston, NC, USA). Radioactive ceramide1-phosphate and phosphatidic acid were isolated by TLC using chloroform/acetone/ methanol/acetic acid/water $(50: 20: 15: 10: 5$, by vol) and then scraped before counting radioactivity by liquid scintillation.

Alternatively, ceramide was determined by liquid chromatography-mass spectrometry. Jurkat cells $\left(5 \times 10^{6}\right)$ (clone A3) were sedimented, washed in PBS and transferred into glass vials. Sphingolipid extracts, fortified with internal standards, were prepared and analyzed by liquid chromatography-mass spectrometry using a Waters Aquity UPLC system connected to a Waters LCT Premier orthogonal accelerated time-of-flight mass spectrometer (Waters, Milford, MA, USA), operated in positive electrospray ionization mode under the conditions previously reported. ${ }^{45}$

Metabolic labeling of sphingolipids. Cells $\left(3 \times 10^{6}\right)$ were incubated for $48-72 \mathrm{~h}$ in the presence of $0.33 \mu \mathrm{Ci} / \mathrm{ml}\left[{ }^{3} \mathrm{H}\right]$ sphingosine (PerkinElmer, Villebon-surYvette, France) to label sphingolipids to equilibrium. Lipids were extracted and separated by TLC using chloroform/methanol/water (100:42:6, by vol). Radiolabeled sphingolipids were detected using a Berthold radiochromatoscanner, identified using lipid standards and then scraped before counting radioactivity by liquid scintillation. Alternatively, $3 \times 10^{6}$ cells were incubated for $48-72 \mathrm{~h}$ in the presence of $1 \mu \mathrm{Ci} / \mathrm{ml}\left[^{3} \mathrm{H}\right]$ choline (PerkinElmer) to label SM and PC to equilibrium. The extracted SM and PC were separated by alkaline hydrolysis as previously described. ${ }^{46}$

De novo SM synthesis. Cells $\left(3 \times 10^{6}\right)$ were incubated in the presence of $\left[{ }^{3} \mathrm{H}\right]$ choline $(1 \mu \mathrm{Ci} / \mathrm{ml})$ for $4 \mathrm{~h}$ to allow PC labeling and were further incubated for indicated times in the presence or absence of FasL. The cells were then sedimented at $4^{\circ} \mathrm{C}$ by low-speed centrifugation, and cell pellets were immediately frozen at $-20^{\circ} \mathrm{C}$. $\left.{ }^{3} \mathrm{H}\right]$ choline-labeled SM was next quantified after alkaline methanolysis as previously described. ${ }^{46}$

Morphological analysis. Cells were half-diluted in a Trypan blue dye solution ( $0.4 \%$ in PBS) for 5 min and analyzed under a light microscope. At least 300 cells were examined and the percentage of cells exhibiting apoptotic nuclei (i.e., condensed and/or fragmented nuclei) was determined. The percentage of Trypan blue-positive cells did not increase during the first $4 \mathrm{~h}$ of incubation with FasL.

Alternatively, Jurkat and HeLa cells were grown on polylysine slides (VWR, Val de Fontenay, France) and glass coverslips, respectively. Cells were further incubated in the presence or absence of FasL as indicated, fixed in PBS containing $4 \%$ (w/v) paraformaldehyde for 15 min, permeabilized with PBS $0.1 \%$ (w/v) Triton X-100 for 15 min and counterstained with 4,6-diamidino-2-phenylindole (DAPI, $1 \mu \mathrm{g} /$ $\mathrm{ml}$ ) to visualize nuclei. ProLong Gold anti-fade reagent (Invitrogen) was used to mount coverslips on slides and cells were examined under a Leica (Wetzlar, Germany) fluorescence-equipped microscope using a $\times 40$-oil objective. At least 300 cells were examined and the percentage of cells exhibiting apoptotic nuclei was determined. 
Confocal microscopy. HeLa cells were grown on glass coverslips for $24 \mathrm{~h}$ in DMEM supplemented with $10 \%$ FCS. Cells were incubated for $1 \mathrm{~h}$ with or without $40 \mu \mathrm{M}$ zVAD-fmk and were further incubated for $8 \mathrm{~h}$ in the presence or absence of $125 \mathrm{ng} / \mathrm{ml}$ FasL. The indirect immunofluorescence protocol was carried out at room temperature as follows: cells were fixed in PBS containing $4 \%(\mathrm{w} / \mathrm{v})$ paraformaldehyde for $15 \mathrm{~min}$, permeabilized with PBS $0.1 \%$ (w/v) Triton X-100 for $15 \mathrm{~min}$, washed in PBS and stained for $1 \mathrm{~h}$ with primary antibodies diluted in PBS. After several washes in PBS, appropriate secondary antibodies were added for $1 \mathrm{~h}$ Cells were also counterstained with DAPI $(1 \mu \mathrm{g} / \mathrm{ml})$ to visualize nuclei. ProLong Gold anti-fade reagent (Invitrogen) was used to mount coverslips. The cells were examined under a Zeiss (Göttingen, Germany) 510 confocal microscope using $\times 63$-oil objective lens.

Statistical analysis. Results are expressed as means \pm S.E.M. of at least three independent determinations per experiment. Mean values were compared using Student's $t$-test. Differences were considered to be statistically significant when $P<0.05$ ( ${ }^{*} P<0.05 ;{ }^{* *} P<0.01$; ${ }^{* \star} P<0.001$; NS: not significant).

Acknowledgements. We thank Dr. J Blenis (Boston, MA, USA) for providing A3 and I9-2 Jurkat cells. We also thank Dr. J Holthuis (Utrecht, the Netherlands) for the kind gift of HeLa cells overexpressing either SMS1-V5 or SMS2-V5. We are grateful to Dr. G Fabrias and Dr. J Casas (Barcelona, Spain) for mass spectrometry analysis of ceramide and for fruitful discussion. We thank E Dalmau, $\mathrm{P}$ Clavé, $\mathrm{N}$ Therville, JC Lepert, JC Thiers and B Payre for excellent technical assistance. We thank Dr N Andrieu-Abadie, Dr. SC Sorli and Dr. JP Jaffrézou for critical reading of the paper. This study was supported by INSERM, Paul Sabatier University, Grant 3417 from the Association pour la Recherche sur le Cancer (ARC) (to BS) and by a grant from Ligue Nationale contre le Cancer and les comités départementaux du Gers, de l'Aveyron et de la Haute-Garonne (to JP Jaffrézou's group).

\section{Conflict of interest}

The authors declare no conflict of interest.

1. Rieux-Laucat F, Le Deist F, Fischer A. Autoimmune lymphoproliferative syndromes: genetic defects of apoptosis pathways. Cell Death Differ 2003; 10: 124-133.

2. Scaffidi C, Fulda S, Srinivasan A, Friesen C, Li F, Tomaselli KJ et al. Two CD95 (APO-1) Fas) signaling pathways. EMBO J 1998; 17: 1675-1687.

3. Muzio M, Salvesen GS, Dixit VM. FLICE induced apoptosis in a cell-free system. Cleavage of caspase zymogens. J Biol Chem 1997; 272: 2952-2956.

4. Vincenz C, Dixit VM. Fas-associated death domain protein interleukin-1beta-converting enzyme 2 (FLICE2), an ICE/Ced-3 homologue, is proximally involved in CD95- and p55mediated death signaling. J Biol Chem 1997; 272: 6578-6583.

5. Muzio M, Chinnaiyan AM, Kischkel FC, O'Rourke K, Shevchenko A, Ni J et al. FLICE, a novel FADD-homologous ICE/CED-3-like protease, is recruited to the CD95 (Fas/APO-1) death-inducing signaling complex. Cell 1996; 85: 817-827.

6. Li H, Zhu H, Xu CJ, Yuan J. Cleavage of BID by caspase 8 mediates the mitochondrial damage in the Fas pathway of apoptosis. Cell 1998; 94: 491-501.

7. Luo X, Budihardjo I, Zou H, Slaughter C, Wang X. Bid, a Bcl2 interacting protein, mediates cytochrome $c$ release from mitochondria in response to activation of cell surface death receptors. Cell 1998; 94: 481-490.

8. Milhas D, Cuvillier O, Therville N, Clave $\mathrm{P}$, Thomsen M, Levade $\mathrm{T}$ et al. Caspase-10 triggers bid cleavage and caspase cascade activation in FasL-induced apoptosis. $J$ Biol Chem 2005; 280: 19836-19842.

9. Fischer U, Stroh C, Schulze-Osthoff K. Unique and overlapping substrate specificities of caspase-8 and caspase-10. Oncogene 2006; 25: 152-159.

10. Lee KH, Feig C, Tchikov V, Schickel R, Hallas C, Schutze $S$ et al. The role of receptor internalization in CD95 signaling. EMBO J 2006; 25: 1009-1023.

11. Ségui B, Andrieu-Abadie N, Jaffrezou JP, Benoist H, Levade T. Sphingolipids as modulators of cancer cell death: potential therapeutic targets. Biochim Biophys Acta 2006 1758: $2104-2120$

12. Tepper AD, Diks SH, van Blitterswijk WJ, Borst J. Glucosylceramide synthase does not attenuate the ceramide pool accumulating during apoptosis induced by CD95 or anticancer regimens. J Biol Chem 2000; 275: 34810-34817.

13. Watanabe M, Kitano T, Kondo T, Yabu T, Taguchi Y, Tashima M et al. Increase of nuclear ceramide through caspase-3-dependent regulation of the 'sphingomyelin cycle' in Fasinduced apoptosis. Cancer Res 2004; 64: 1000-1007.

14. Bourteele S, Hausser A, Doppler H, Horn-Muller J, Ropke C, Schwarzmann G et al. Tumor necrosis factor induces ceramide oscillations and negatively controls sphingolipid synthases by caspases in apoptotic Kym-1 cells. J Biol Chem 1998; 273: 31245-31251.
15. Separovic D, Hanada K, Maitah MY, Nagy B, Hang I, Tainsky MA et al. Sphingomyelin synthase 1 suppresses ceramide production and apoptosis post-photodamage. Biochem Biophys Res Commun 2007; 358: 196-202.

16. Separovic D, Semaan L, Tarca AL, Awad Maitah MY, Hanada K, Bielawski J et al. Suppression of sphingomyelin synthase 1 by small interference RNA is associated with enhanced ceramide production and apoptosis after photodamage. Exp Cell Res 2008; 314: 1860-1868.

17. Charruyer A, Bell SM, Kawano M, Douangpanya S, Yen TY, Macher BA et al. Decreased ceramide transport protein (CERT) function alters sphingomyelin production following UVB irradiation. J Biol Chem 2008; 283: 16682-16692.

18. Huitema K, van den Dikkenberg J, Brouwers JF, Holthuis JC. Identification of a family of animal sphingomyelin synthases. EMBO J 2004; 23: 33-44.

19. Yamaoka S, Miyaji M, Kitano T, Umehara H, Okazaki T. Expression cloning of a human cDNA restoring sphingomyelin synthesis and cell growth in sphingomyelin synthasedefective lymphoid cells. J Biol Chem 2004; 279: 18688-18693.

20. Luberto $C$, Hannun YA. Sphingomyelin synthase, a potential regulator of intracellular levels of ceramide and diacylglycerol during SV40 transformation. Does sphingomyelin synthase account for the putative phosphatidylcholine-specific phospholipase C? J Biol Chem 1998; 273: $14550-14559$

21. Tafesse FG, Huitema K, Hermansson M, van der Poel S, van den Dikkenberg J, Uphoff A et al. Both sphingomyelin synthases SMS1 and SMS2 are required for sphingomyelin homeostasis and growth in human HeLa cells. J Biol Chem 2007; 282: 17537-17547.

22. Itoh M, Kitano T, Watanabe M, Kondo T, Yabu T, Taguchi $\mathrm{Y}$ et al. Possible role of ceramide as an indicator of chemoresistance: decrease of the ceramide content via activation of glucosylceramide synthase and sphingomyelin synthase in chemoresistant leukemia. Clin Cancer Res 2003; 9: 415-423.

23. Yang Z, Khoury C, Jean-Baptiste G, Greenwood MT. Identification of mouse sphingomyelin synthase 1 as a suppressor of Bax-mediated cell death in yeast. FEMS Yeast Res 2006; 6: 751-762.

24. Kilkus JP, Goswami R, Dawson SA, Testai FD, Berdyshev EV, Han X et al. Differential regulation of sphingomyelin synthesis and catabolism in oligodendrocytes and neurons. J Neurochem 2008; 106: 1745-1757.

25. Hanada K, Kumagai K, Yasuda S, Miura Y, Kawano M, Fukasawa M et al. Molecular machinery for non-vesicular trafficking of ceramide. Nature 2003; 426: 803-809.

26. Swanton C, Marani M, Pardo O, Warne PH, Kelly G, Sahai E et al. Regulators of mitotic arrest and ceramide metabolism are determinants of sensitivity to paclitaxel and other chemotherapeutic drugs. Cancer Cell 2007; 11: 498-512.

27. Van der Luit AH, Budde M, Zerp S, Caan W, Klarenbeek JB, Verheij M et al. Resistance to alkyl-lysophospholipid-induced apoptosis due to downregulated sphingomyelin synthase 1 expression with consequent sphingomyelin- and cholesterol-deficiency in lipid rafts. Biochem J 2007; 401: 541-549.

28. Miyaji M, Jin ZX, Yamaoka S, Amakawa R, Fukuhara S, Sato SB et al. Role of membrane sphingomyelin and ceramide in platform formation for Fas-mediated apoptosis. J Exp Med 2005; 202: 249-259.

29. Ding T, Li Z, Hailemariam T, Mukherjee S, Maxfield FR, Wu MP et al. SMS overexpression and knockdown: impact on cellular sphingomyelin and diacylglycerol metabolism, and cell apoptosis. J Lipid Res 2008; 49: 376-385.

30. Hailemariam TK, Huan C, Liu J, Li Z, Roman C, Kalbfeisch M et al. Sphingomyelin synthase 2 deficiency attenuates NFkappaB activation. Arterioscler Thromb Vasc Biol 2008; 28: 1519-1526

31. Cifone MG, Roncaioli P, De Maria R, Camarda G, Santoni A, Ruberti G et al. Multiple pathways originate at the Fas/APO-1 (CD95) receptor: sequential involvement of phosphatidylcholine-specific phospholipase $\mathrm{C}$ and acidic sphingomyelinase in the propagation of the apoptotic signal. EMBO J 1995; 14: 5859-5868.

32. Samraj AK, Keil E, Ueffing N, Schulze-Osthoff K, Schmitz I. Loss of caspase-9 provides genetic evidence for the type I/II concept of CD95-mediated apoptosis. J Biol Chem 2006; 281: 29652-29659.

33. Jin ZX, Huang CR, Dong L, Goda S, Kawanami T, Sawaki T et al. Impaired TCR signaling through dysfunction of lipid rafts in sphingomyelin synthase 1 (SMS1)-knockdown T cells. Int Immunol 2008; 20: 1427-1437.

34. Walker A, Ward C, Sheldrake TA, Dransfield I, Rossi AG, Pryde JG et al. Golgi fragmentation during Fas-mediated apoptosis is associated with the rapid loss of GM130. Biochem Biophys Res Commun 2004; 316: 6-11.

35. Gulbins E, Kolesnick R. Raft ceramide in molecular medicine. Oncogene 2003; 22: 7070-7077.

36. Villani $M$, Subathra $M, \operatorname{Im} Y B$, Choi $Y$, Signorelli $P$, Del Poeta $M$ et al. Sphingomyelin synthases regulate production of diacylglycerol at the Golgi. Biochem J 2008; 414: 31-41.

37. van Blitterswijk WJ, van der Luit AH, Veldman RJ, Verheij M, Borst J. Ceramide: second messenger or modulator of membrane structure and dynamics? Biochem J 2003; 369. 199-211.

38. Ouasti S, Matarrese P, Paddon R, Khosravi-Far R, Sorice M, Tinari A et al. Death receptor ligation triggers membrane scrambling between Golgi and mitochondria. Cell Death Differ 2007; 14: 453-461.

39. Hu W, Xu R, Zhang G, Jin J Szulc ZM, Bielawski J et al. Golgi fragmentation is associated with ceramide-induced cellular effects. Mol Biol Cell 2005; 16: 1555-1567. 
40. Ternes P, Brouwers JF, van den Dikkenberg J, Holthuis JC. Sphingomyelin synthase SMS2 displays dual activity as ceramide phosphoethanolamine synthase. J Lipid Res 2009 (in press).

41. Bankaitis VA, Morris AJ. Lipids and the exocytotic machinery of eukaryotic cells. Curr Opin Cell Biol 2003; 15: 389-395.

42. Shimizu M, Fontana A, Takeda Y, Yagita H, Yoshimoto T, Matsuzawa A. Induction of antitumor immunity with Fas/APO-1 ligand (CD95L)-transfected neuroblastoma neuro-2a cells. J Immunol 1999; 162: 7350-7357.

43. Juo P, Kuo CJ, Yuan J, Blenis J. Essential requirement for caspase-8/FLICE in the initiation of the Fas-induced apoptotic cascade. Curr Biol 1998; 8: 1001-1008.
44. Van Veldhoven PP, Matthews TJ, Bolognesi DP, Bell RM. Changes in bioactive lipids, alkylacylglycerol and ceramide, occur in HIV-infected cells. Biochem Biophys Res Commun 1992; 187: 209-216.

45. Munoz-Olaya JM, Matabosch X, Bedia C, Egido-Gabas M, Casas J, Llebaria A et al. Synthesis and biological activity of a novel inhibitor of dihydroceramide desaturase. ChemMedChem 2008; 3: 946-953.

46. Segui B, Andrieu-Abadie N, Adam-Klages S, Meilhac O, Kreder D, Garcia V et al. CD40 signals apoptosis through FAN-regulated activation of the sphingomyelin-ceramide pathway. J Biol Chem 1999; 274: 37251-37258.

Supplementary Information accompanies the paper on Cell Death and Differentiation website (http://www.nature.com/cdd) 